\title{
Reconstruction and Institutional Sovereignty of Oil and Gas Mining Management Based on Access to Justice
}

\author{
Imam Koeswahy ono \\ Faculty of Law \\ Brawijaya University \\ Malang, Indonesia \\ imam.koes@ub.ac.id
}

\begin{abstract}
The legal issues are related to how the state sovereignty in terms of planning, implementation, control, and evaluation over exploration and exploitation by investors is implemented according to the principles of the power of the state in mining regions. What arises as a problem is how the freedom of state sovereignty of mining regions should be performed independently or with the intervention of foreign countries. This paper examines how state souvereignty over the management of oil and gas, especially in the form of a work contract, raises disputes over land rights with indigenous law communities and is not capable of providing welfare for the community as mandated by the constitution. Various cases are faced by the government of the Republic of Indonesia in the management of oil and gas managed by PT. Pertamina, and the production sharing contract is the most vulnerable sectors to corru ption. This is due to the high profits generated from oil and gas industry, thus potentially creating high rent seeking activities that utilize their political positions and connections to seek profit through this illegal act. The final result of this study is to find the arrangement of regulation and institutional management of oil and gas mining which is not only aligned with the essence of the philosophical value based on Pancasila principles, Article 33 of the Constitution of the Republic of Indonesia. It is widely accepted that the state sovereignty of mining and natural gas resources are managed fairly and entirely for the welfare and prosperity of the society.
\end{abstract}

Keywords - reconceptualization, reconstruction, sovereignty, legal recognition, access to justice

\section{INTRODUCTION}

Indonesia has a long history of oil exploration, with the Dutch drilling in the late 1800 s. Companies such as Shell have been operating in Indonesia for over 100 years. In the 1960s, under the former President Suharto, Pertamina (the main Indonesian state-owned oil and gas company) was set up to function as both an oil company and as the state's chief energy regulator. Pertamina both controlled and supervised oil and gas operations under various production sharing contracts. During this time, most of the companies exploring and producing oil in Indonesia were foreign companies, having invested billions of dollars setting up their operations. From the perspective of legal history there are dynamics of oil and gas mining policy and regulation in Indonesia on the one hand. On the other hand, there have been interesting dynamics to study from the results of studies from the law department of the Ministry of Energy and Mineral Resources in a series of laws and regulations governing oil and gas since the enaction of Law Number 44/PRP/1960 concerning Oil and Natural Gas, Law Number 8 of 1971 concerning Oil and Natural Gas Companies, and Law Number 22 of 2001 concerning Oil and Gas before and after the Decision of Constitutional Court on judicial review regarding Oil and Natural Gas was enacted [1]. Based on the Law on oil and gas Number 22 of 2001 mining rights are owned by the state as an institutional entity as the holder of the mandate of the entire nation according to Article 33 Paragraph 3 of the 1945 Constitution. Through the right to control fro $m$ the state as an instrument, the government can hand it over to the cooperative or the private sector. Thus, the government, in this case the Ministry of Energy and Mineral Resources, holds the mining authority by providing certain work areas for exploration and continued exploitation. Upstream oil and gas industries based on Article 11 Paragraph 1 of the oil and gas law are carried out by a business entity or permanent establishment based on a cooperation contract with the implementing agency. Thus, the business entity or permanent establishment has the following characteristics:

a. It does not have ownership rights of oil and gas natural resources (mineral right)

b. It does not hold mining rights;

c. It is not authorised for operational management as well

d. It receives compensation from production results or does not have control over the work plan, budget, and field development plan (economic rights).

Referring to Government Regulation Number 79 of 2014 concerning National Energy Policy, the policy of energy and mineral resources sector by linking with other laws and regulations, Law Nu mber 4 of 2009 concerning Mineral and Coal Mining, Law Nu mber 30 of 2009 concerning Electricity and Law No. 21 of 2014 concerning Geothermal are used as the basis for the preparation of the National Energy General Plan and the Regional Energy General Plan. Many cases faced by the government of the Republic of Indonesia regarding oil and natural gas management by PT Pertamina regulated in cooperation agreements show that this business sector vulnerable to corruption. This is due to the high profits generated from the oil and gas industry, thus potentially creating high rent for both exploration and exploitation activities that utilize their legal positions and connections to 
seek profit through corruption[2][3]. ${ }^{1}$ Ilham M Putuhena's research introduces four models of oil and gas management after the decision of the Republic of Indonesia Constitutional Court, namely: instituting SKK Migas permanently, giving back the authority to Pertamina, directly appointing the manager on behalf of the state by the government, establishing a new State-Owned Enterprise (hereinafter BUMN) or a new institution. It is recommended that the government, together with the House of Representatives and the Regional Representative Council, forms a constitutional institution based on the Constitutional Court Decision Number 36 / PUU-X / 2012 where the court is of the opinion that Law Number 22 Year 2001 in relation to oil and gas governance BP Migas has degraded the meaning of state ownership rights over natural resources, especially oil and gas [4].

The ratio legis is the essence of reformulation of the concept of rights to control the state over oil and natural gas resources in Indonesia, which is expected to be in harmony with the meaning of state sovereignty regarding oil and natural gas management that serves as a constitutional basis of oil and natural gas management. As a consequence, fair management of oil and natural gas based on the constitution, in a good order/ with legal certainty can be achieved for the welfare of the whole citizens of Indonesia.

compare a critical analysis of Prima Gandhi which mentioned that Indonesia's natural resources in the form of petroleum and natural gas are currently the majority controlled by a foreign party. This is because the amount of capital needed and lack of human resources (HR) that master technology related to the exploitation process Oil and Gas. After the Time Life Corp conference in Geneva and the enactment of the Planting Law Foreign Capital in 1967. Foreign corporations began to exploit oil and gas in Indonesia. Initially several oil and gas mult inational corporations such as Total, British Petroleum, Exxon The car only manages the upstream oil and gas business sector. However, Law number 22 Year of 2001 concerning oil and gas, making foreign corporations have the opportunity to do business in the downstream sector. The proof is currently Shell, Petronas from Malaysia and Total gas stations are already established in several major cities in Indonesia. At the end of May 2009, the Ministry of Energy and Mineral Resources data showed 69.9 percent of foreign domination in Indonesia's oil and gas industry, about 70 percent of which are USbased companies such as Chevron, Conoco Philips and Exxon Mobil The national oil and gas company is only 29.1 percent in the oil and gas industry. Especially for the natural gas sector, reports from Energy The Information Administration (EIA) in January 2008 stated that 90 percent of the total Indonesian natural gas production comes from 6 MNCs namely, Total (30 percent), Exxon Mobil (17percent), Vico (BP-Migas joint venture 11 percent), Conoco Philips (11 percent), BP (6 percent) and Chevron (4 percent).Of Oil production in Prima Gandhi.,2014.

Refers to qualitative Analysis of the Value of Indonesian Gas Exports and Ownership of Oil and Gas Blocks by Foreigners in the Journal of Agriculture, Resource and Environmental Economics, Bogor Institute of Agriculture's Department of Agriculture, Bogor, pp. 2 Compare this with critical reviews and the failure of Indonesia's condition which was in a manifesto of Noer Fauzi Rachman who questioned the sustainability of state organizations and the management of natural resources including oil and natural gas in strong foreign penetration including international financial organizations. See Noer Fauzi Rachman. (2017) Panggilan Tanah Air (Call of the Fatherland), Third Print, Insist Press, Yogyakarta, referring to Fernand Braudel's (Annales School, 1979) and David Harvey's 2006 views with the dominant ideology of neo-capitalism and neo-liberalism which began with colonial condemnation the hypothesis is that ultimately Indonesia's sovereignty has almost collapsed against the penetration of foreign pressure, international institutions, while on the majority of the nation's citizens experience poverty p.26-33

\section{LEGAL ISSUE}

The legal is sue is how to realise the dynamic and precise state sovereignty over oil and natural gas resources management and its supervision in Indonesia either at exploration or exploitation level according to maxim uti possidetis or absolute sovereignty of a state regarding oil and gas, following the principle of freedom, and it should be independent from foreign companies?

\section{THE AIM OF THIS PAPER}

This paper examines how state sovereignty over the management of oil and gas, especially in the form of a work contract, raises dis putes over land rights with indigenous law communities and is not capable of providing welfare for the community, especially for the Local Community as mandated by the constitution

\section{THEORETICAL FRAMEWORK AND LEGAL METHOD}

Through normative legal research with conceptual approach, this research is aimed to study the meaning of the concept of state sovereignty rights, concession, contract of work, production sharing contract (PSC) and cooperation contract, and access to justice and statute approach through reviewing a series of history of legislation since Staatsblad 1899 No.214 jo S 1906 No.434, the 1945 Constitution of the State of the Republic of Indonesia Article 33, Law No.5 of 1960, Decree of People's Consultative Assembly (MPR) No.IX / MPR / 2001, Law No.44 / PRP / 1960, Law No.8 Year 1971, Law No.22 of 2001, Decision of the Constitutional Court No.36 / PUU-X / 2012 as well as Minutes of Discussion and Academic Paper of related Law. Based on primary legal materials, prescriptive analysis is done through hermeneutic interpretation method as an attempt to find the meaning of text according to the context of legal problem. Steps are taken in consecutive assessment: collecting, classifying, categorising, systematising legal materials according to the history of state policies and regulations. The obtained data is then interpreted hermeneutically, so that the concepts and constructions that rebuild should be made. The second argument is from the perspective of access to justice[5] in particular, people as owners of natural resources, especially oil and gas, with critical questions to be answered are: what is the significance of access to obtain justice for the marginalized people?, what reforms are proposed by these approaches to legal development cooperation? Conceptually, dispute resolution between government and investors is considered too sensitive due to political influences and an intention or a vision to change oil and natural gas management based on formal regulation of the state and any regulations out of the context of the state or Adat to measure the realisation of the outcome in the view of either justice or benefit.

\section{DISCUSSION}

Referring to Affina Niken Al-Islami's research on legal implications of the is suance of Presidential Regulation No. 9 of 2013 and the Regulation of the Minister of Energy and Mineral Resources No. 9 of 2013 on existence of the Oil and Gas Special Task Force, it is stated that SKK Migas is not $a$ rechtspersoon; it is not a perfect legal subject because it is a work unit so that it aligns the position of the government on behalf of the state in line with investors [6]. In addition, the access for indigenous people to prior informed consent that 
eliminates fundamental rights breeds conflicts with complex configurations of various actors and diverse economic, political and cultural interests through legalization, among other licensing agencies which are conceptually contradictory. ${ }^{2}$ As an effort to complement the case study materials to get valuable lesson that can be learned, this paper refers to Bolivia's experience in natural gas management. Bolivia government has succeeded in mainstreaming the aspirations of natural resource governance based on local wisdom in the political discourse on the Quechua and Aymara tribes with a series of protests by utilizing the weakness of government[7]. Based on The Bolivia government experience and referring to the Article of the Decree of the People's Consultative Assembly Nu mber IX / MPR / 2001 concerning Agrarian Reform and Natural Resource Management, a fundamental effort is required for the government to carry out policies to reconstruct regulations, institutions and relations between stakeholders related to natural resources, especially oil and natural gas based on the interests of the nation and local wisdom. In relation to this thought, the government needs to take the initiative to directly take the leading role to implement governance as the authorised body to conduct mining activities.

The results of the study of Maria SW Sumardjono et. al. in 2008-2009 in the context of the Oil and Gas Law the legal relationship between subject (human) and natural resources of oil and gas management were only focused on the rights or authority (bevoegd) of the subjects who conduct the supervision. Meanwhile, the philosophy of legal relations between countries in this case the government is based on the constitutional mandate of the Indonesian nation, with natural resources lacking attention as stated in Article 4 Paragraph (1) on Mining Law but prioritizing pragmatic aspects (het pragmatisch denken) both on upstream business and downstream. There is confusion over the placement of the first government position, as an authority over state control according to Article 4 Paragraph (2) and Article 6 Paragraph (2) as an owner (eigenaar) as in a Cooperation Contract. Government as a public institution has the authority to regulate and supervise the use of oil and gas. The first view is that the government grants business licenses for business entities that undertake downstream business activities placed unilaterally without the consent of the permit recipient to determine the rights and obligations of business actors. The law must be reconciled on the meaning of state control which occupies as a private entity that is the owner (eigendom recht) towards the second meaning of regulating and supervising oil and gas business. The author argues that private entities mostly care about making as much profits as possible without much concern on profit share. This is certainly irrelevant to the principle of humanity and social justice for all societies in Indonesia (het Integralistiek Staat). Such a state reflects the synthesis or harmonious combination of ideological trilogy with religious direction, nationality and socialism, especially the principles of social justice and a just and civilized humanitarian principle. In line with this concept, the authority of the state as a public institution includes: conservation of resources, environmental management, development of the

2 see The Van Vollenhoven Institute Law Governance and Development Project Report of Universiteit van Leiden, BAPPENAS: 2011 Recommendation of the Future Policy on Communal Land Rights: Some Ideas For Legal Recognition: 14-20 environment and local communities, occupational safety and health, types and quality of oil and gas processed products, allocation and distribution of oil and gas fuels, the use of foreign workers and so on.[8]. ${ }^{3}$ Essentially, the meaning of Article 33 Paragraph (2) of the 1945 Indonesian Constitution states that Production sectors that are vital to the state and that affect the livelihood of a considerable part of the population are to be controlled by the state. The use of it must be controlled by the government responsible for the people's sovereignty in the form of a public permit ${ }^{4}$. As an effort to confirm and realize the rule of law state of Pancasila (het Pantjasila rechtsstaat), a review of the products of laws and regulations whose value contradicts Pantjasila, including Oil and Gas Law, is needed to change institutions whose authority overlaps and weakens state institutions permanently and reclaim economic independence in the realization of the Pantjasila economic system that is independent, efficient, through the revitalization of the role of the state in the control of the earth, water, and natural wealth contained in it as the core content of the prosperity of all people who are just[9]. ${ }^{5}$

The state, according to Mohammad Hatta, does not need to be an ondernemer / businessman but it has to make regulations to accommodate the work of the Pantjasila economic system and prohibits exploitation of citizens of the weak nation by capitalists (exploitation de l'homme par l'homme). The strategy that must be carried out in negotiating the formulation of oil and gas resource cooperation contracts between the government and foreign investors is sixty percent for the state, thirty percent for investors, and ten percent for local governments. Roads or canalization for citizens who are in disadvantaged positions or experience injustice, including the customary law community in oil and gas mining business activities, carried out through the access to justice mechanism in the agrarian court $^{6}$ which is assigned to the general court according to the

3 Adrian Sutedi.,2012., Hukum Pertambangan (Mining Law), Second Print, Sinar Grafika, Jakarta, pp. 71-74 compare the results of the research of Robert Kratsas and Jennifer A Parnelll in 1985-1993 in the Pagerungan of ARCO governance in Ian A. Bowles, Glenn T. Prickett. (2001). Footprints in the Jungle: Natural Resource Industries, Infrastructure and Biodiversity Conservation. Oxford University Press. New York, pp. 73-87 by demonstrating the success and excellence of environmental management through information systems and complaints about the environment, integrated complaints regarding the environmental assessment systems both technical, and social impact.Based on the percentage of profit sharing between the government and ARCO whether in real terms the impact of prosperity on the community, how much profit is the oil and gas exploitation received by the government that flows, especially around business activities, precisely the latter becomes the most important thing.

4 Permit according to Article 1 number 19 of Law Number 30 of 2014 concerning Government Administration is the decision of the authorized government official as a form of agreement on the request of the community in accordance with the provisions of the legislation.

5 Compare this with Yudi Latif., 2015., The Pancasila Revolution, First Print, Mizan, Jakarta, pp. 173-175 which states that radical movements in embodying Pancasila-based revolutions are intended to rebuild the citizens' mentality and morality and rearrange policies, arrangements the institutional and governance system that correctly realizes the essence of Pantjasila values by not repeating the error in the New Order era of 1966-1998 in translating and realizing these values.

6 An agrarian court is an ad hoc court system which is formed by law in the form of a panel judge / assembly whose composition is determined according to the basic needs of the dispute consisting of Indigenous community leaders, peasant / fishermen figures, non-government organizations, professional judges, local cultural / community figures and / or Customary law communities, as well as representatives 
Judicial Power Act Nu mber 48 of 2009 Artic le 1 number 5 to carry out the judiciary in accordance with the principle of Godhead, upholding law and justice based on Pantjasila ideology, as well as the principle of simplicity, efficiency, and affordability.

\section{CONCLUSION AND RECOMMENDATIONS}

\section{A. Conclusion}

Conclusion the sovereignty of the state is permanently in the form of state control over oil and natural gas in Indonesia for exploration and exploitation activities as maxim $u t i$ possidetis in the form of freedom tangible the right to exercise regardless of influence of foreign elements carried out with concrete efforts, continuously by reviewing and arranging policies, arrangements and institutions in the management of oil and gas as a form of national sovereignty over natural resources.

\section{B. Recommendation}

1. The government in reviewing and arranging policies, arrangements, and institutions in the management of oil and gas as a whole as a form of national sovereignty over natural resources, should consider multistakeholders such as BAPPENAS, Ministry of Energy and Mineral Resources, AMAN, KLHK, Ministry of ATR, Ministry of EKUIN

2. The government is expected to form an agrarian justice institution as an ad-hoc court that will resolve natural resource disputes in a legal and fair manner.

\section{REFERENCES}

[1] “No T itle," Kompas Newspaper, p. 12, 2016.

[2] W. Sunarya and G. A. Taufik, Introduction to Oil and Gas Law in Indonesia (Pengantar Hukum Minyak dan Gas Bumi Indonesia). Depok: Kantor Hukum Wibowo dan Rekan, 2017.

[3] N. F. Rachman, Call of the Fatherland (Panggilan Tanah Air), 3rd ed. Yogyakarta: Insist Press, 2017.

[4] I. M. Putuhena, "Politik Hukum Pengelolaan Hulu Migas Pasca Putusan Mahkamah Konstitusi," Rechtsvinding, vol. 4, no. 2 Agustus, p. 237, 2015.

[5] I. van de Meene and B. van Rooij, Access to Justice. Leiden, The Netherlands: Leiden University Press, 2008.

[6] A. N. Al-Islami, "Legality of Oil and Gas Cooperation Contracts on Organizations and Practices of the Oil and Gas Special Work Unit Based on Presidential Regulation Number 9 of 2013 and Regulation of the Minister of Energy and Mineral Resources Republic of Indonesia Number,"Brawijaya University, 2013.

[7] T. Perreault, Natural Gas, Indigenous Mobilization and Bolivian State, Identities, Conflict and Cohesion Programme Paper Number 12. Geneve, Switzerland: United Nations Research Institute for Social Development and IFAD Enabling Poor Rural People to Overcome Poverty, 2008.

[8] A. Sutedi, Mining Law (Hukum Pertambangan), Second. Jakarta: Sinar Grafika, 2012.

[9] Y. Latif, The Pancasila Revolution, First. Jakarta: Mizan, 2015.

ministries / departments / agencies and local governments. Comparatively referring to Article 3.4 letters of $\mathrm{c}, \mathrm{e}, \mathrm{f}, \mathrm{h}, \mathrm{j}$ and the Decree of the People's Consultative Assembly Number IX / MPR / 2001 concerning Agrarian Reform and Natural Resource Management. Access to justice should not only be known but also understood its meaning and most importantly applied in community life. Access to justice (access to justice) is defined as an opportunity to get justice this applies to all circles or is often referred to as justice for all. 
